\title{
28 Research Square \\ In Vitro Antisickling Activity of Moringa Oleifera Extracts on Sickle Cells
}

Rayan Hamid Omer

Alzaiem Alazhari University

Nusiba Abdullah Yousif

Alzaiem Alazhari University

Toga Abdalazim Fadlalla

Alzaiem Alazhari University

Wala Eldin Osman Elradi

Alzaiem Alazhari University

Mohamed Mobarak Elbasheir ( $D$ mbasheir@hotmail.com )

https://orcid.org/0000-0001-8113-0779

Elharam Ibrahim Abd allah

Alzaiem Alazhari University

Research

Keywords: In vitro, Anti-sickling activity, Moringa Oleifera, Sickle cell disease, Khartoum State, Sudan

Posted Date: June 9th, 2020

DOI: https://doi.org/10.21203/rs.3.rs-32121/v1

License: (c) (i) This work is licensed under a Creative Commons Attribution 4.0 International License.

Read Full License 


\section{Abstract}

Background: Sickle cell disease is one of the major haemoglobinopathies affecting African people, in Sudan many children are suffering from this disease. Numerous studies revealed that some medicinal plants have shown an antisickling activity, which may be a new therapeutic way to a range of people who are affected by this disease. Particularly that, chemical treatment is cost effective and has many side effects. The study aimed to evaluate in vitro antisickling effect of Moringa Oliefera on sickle cells.

Materials and methods: Using seeds and leaves crude (methanol extract and aqueous extract), the in vitro antisickling activities of Moringa oleifera fractions, were evaluated using erythrocyte cells deoxygenated with $2 \%$ sodium metabisulphite. Normal saline was employed as an internal negative control.

Results: All extracts revealed high anti sickling activity in deoxygenated erythrocytes $(P<0.05)$ when compared with the negative control.

Conclusions: Findings from the present study suggest the antisickling potential of the seeds and leaves of Moringa oleifera.

\section{Background}

Sickle cell disease (SCD) is an ignored tropical disease [1], its global load has continued to increase in low and middle-income countries especially in sub-Saharan Africa [2]. It is an overwhelming genetic disorder affecting $2.3 \%$ of the world population, mainly in Africa [3]. Sickle cell disease or sickle cell anemia (SCA) also called drepanocytosis is an autosomal recessive disease caused by a single point mutation in the codon of the sixth nucleotide of the beta globin chain. This mutation leads to substitution of the polar amino acid glutamic acid by the non polar one valine [4]. This amino acid substitution alters not only the affinity of hemoglobin toward oxygen but also its solubility under low oxygen pressure conditions. This reduction in solubility causes the hemoglobin polymerization and the sickling of red blood cells, which induce painful vaso-occlusive crises, chronic hemolytic anemia and other sicklers' problems [1]. Even though sickle cell disease causes significant morbidity and mortality and affects the economic and healthcare status of many countries. however historically, the disease has not had proportionate outlays of funds that have been aimed at research and development of drugs and treatment procedures for other diseases [5]. Currently, hydroxyurea $(\mathrm{HU})$ is the only medical modality with proven efficacy in patients with frequent symptoms related to SCA [6].

As the prevalence of sickle cell diseases is still increasing in Sudan, and the poor economic situation of the population, yet the treatment and management of sickle cell anaemia is very expensive with adverse effects of treatments. Therefore, this study is intended to evaluate whether the extraction of different parts of Moringa plants could be effective way of combating sickling process thus decreasing the cost and side effects of the ordinary treatment.

\section{Materials And Methods}


This experimental study was done in Khartoum state from September 2019 to January 2020. The study population were ten sickle cell anemia samples obtained from known diagnosed sickle cell disease patients (HBSS) admitted to Khartoum teaching hospital.

\section{Inclusion and exclusion criteria}

Samples were collected from SCD patient, including both genders with different age. Patients with other hereditary disorders and cancer were excluded.

\section{Study design and plant materials}

This experimental study was evaluated the anti sickling activity of Moringa Oleifera leaves and seeds extracts both aqueous and methanol fractions at a concentration of $20 \mathrm{mg} / \mathrm{ml}$ depending on previous study by Mpiana et al., [3] who worked at a concentration range between 0 and $10 \mathrm{mg} / \mathrm{ml}$ for the antisickling activity of anthocyanins from Ocimum basilicum.

Fresh leaves, seeds and flowers of Moringa Lam. were harvested from Moringa Oleifera tree in Khartoum state. The tree is identified by botanist, the leaves and seeds were dried at room temperature, milled and weighed. The powder was extracted by cold maceration in absolute methanol for 72 hrs after which it was filtered and evaporated to dryness in vacuo at $40^{\circ} \mathrm{C}$. The crude extract obtained was further fractionated into methanol and water. All extracts were subjected to antisickling assays.

\section{Preparation of Methanolic Extract}

Extraction was carried out according to the method described by previously. Briefly, $100 \mathrm{gm}$ of the plant sample was coarsely powdered using mortar and pestle. Coarsely a sample was soaking with absolute methanol. Extraction carried out for three days with daily filtration and evaporation the solvent under reduced pressure using rotary evaporator apparatus. Sample extract was allowed to air in evaporating dish till complete dryness and the yield percentages were calculated as follows:

About $4 \mathrm{ml}$ EDTA blood sample was obtained from patients and centrifuged at 3000 rpm for 10 minutes to remove the plasma. The resulting packed erythrocytes was washed 3 times with 1 ml sterile normal saline per $5 \mathrm{ml}$ of blood. The sample then was centrifuged each time to remove the supernatant. Washed $\mathrm{RBC}$ then re-suspended in remaining suspension and was used for the analysis.

\section{Procedure for anti-sickling activity evaluation}

Washed erythrocyte was mixed with an equivalent volume of $2 \%$ sodium metabisulfite (Na205S2). $10 \mu l$ from the above mixture was spotted on a microscope slide then $10 \mu \mathrm{l}$ from each plant extracts (aqueous leaves extract, methanol leaves extract, aqueous seeds extract and methanol seeds extract), each one of them was added and mixed with the blood mixture. $10 \mu \mathrm{l}$ normal saline was added to one of the slides 
instead of the plant extract which served as internal negative control; all the slides was covered with a cover slip. Paraffin was applied to seal the edges of the cover completely to exclude air (hypoxia), and then, slides were incubated at $37^{\circ} \mathrm{C}$ for 2-period interval (immediately and 60 minutes). Each slide was examined under the oil immersion light microscope, and RBCs was counted in five different fields of view across the slide. The numbers of both sickled and unsickled blood cells was determined, and the percentage of unsickled cells was calculated.

\section{Ethical considerations}

Approval for this study was obtained from Ethical committee of Alzaeim Alazhari University and permission from the administrators of Khartoum teaching hospital. Research purpose and objectives were explained to participant in a clear simple words. Participant has right to voluntary, verbal informed consent. Data were obtained with privacy.

\section{Statistical analysis}

Data were analysed using Statistical package for the social sciences (SPSS) version 21.0 software (SPSS for Windows). Independent $T$ test at $5 \%$ level of significant was performed to determine the means (Standard Deviation) of percentage of unsickled cells during two incubation period interval. The percentage of unsickle cells was calculated using the formula:

Percentage of unsickling cells $=$ Number of unsickling cells $\times 100 /$ Total cells

\section{Results}

The means (SD) percentage of unsickled cells for different moringa oleifera extract at two incubation interval; immediately and after one hour incubation was shown in Table 1. Difference between percentage of un sickle among seeds extracts and control was shown in Table 2. All seeds extracts revealed a significant difference when compared to control $P$ value $(<0.05)$. 
Table 1

Descriptive statistic of percentage of unsickle cells among Moringa oleifera extracts and control

\begin{tabular}{|c|c|c|c|c|c|c|}
\hline & & $\mathbf{N}$ & Minimum & Maximum & Mean & $\begin{array}{l}\text { Std. } \\
\text { Deviation }\end{array}$ \\
\hline \multirow{4}{*}{$\begin{array}{l}\text { Seeds } \\
\text { Extract }\end{array}$} & $\begin{array}{l}\text { \%of un sickle aqueous- } \\
\text { Immediately }\end{array}$ & 10 & 85.6 & 99.7 & 94.7 & 4.7 \\
\hline & $\begin{array}{l}\text { \%of un sickle aqueous- } 1 \mathrm{hr} \\
\text { incubation }\end{array}$ & 10 & 97.5 & 99.9 & 99.0 & 0.7 \\
\hline & $\begin{array}{l}\text { \%of un sickle Methanol - } \\
\text { Immediately }\end{array}$ & 10 & 82.8 & 100.0 & 94.9 & 4.8 \\
\hline & $\begin{array}{l}\text { \%of un sickle Methanol - } 1 \mathrm{hr} \\
\text { incubation }\end{array}$ & 10 & 97.1 & 100.0 & 98.7 & 1.0 \\
\hline \multirow{4}{*}{$\begin{array}{l}\text { Leafs } \\
\text { Extract }\end{array}$} & $\begin{array}{l}\text { \%of un sickle aqueous- } \\
\text { Immediately }\end{array}$ & 10 & 81.2 & 99.6 & 93.3 & 5.7 \\
\hline & $\begin{array}{l}\text { \%of un sickle aqueous- } 1 \mathrm{hr} \\
\text { incubation }\end{array}$ & 10 & 93.6 & 100.0 & 97.9 & 1.8 \\
\hline & $\begin{array}{l}\text { \%of un sickle Methanol - } \\
\text { Immediately }\end{array}$ & 10 & 82.2 & 100.0 & 92.3 & 6.1 \\
\hline & $\begin{array}{l}\text { \%of un sickle Methanol - } 1 \mathrm{hr} \\
\text { incubation }\end{array}$ & 10 & 97.2 & 100.0 & 98.4 & 1.1 \\
\hline Control & \%of un sickle in control & 10 & 8.0 & 91.5 & 64.6 & 28.7 \\
\hline
\end{tabular}

Table 2

Percentage of unsickle cells among seeds extract and control

\begin{tabular}{|c|c|c|c|c|}
\hline & $\mathbf{N}$ & Mean & Std. Deviation & $P$.value \\
\hline Aqueous seeds extract - Immediately & 10 & 94.7 & 4.7 & 0.009 \\
\hline Control & 10 & 64.6 & 28.7 & \\
\hline Aqueous seeds extract $-1 \mathrm{~h}$ & 10 & 99.0 & 0.7 & 0.004 \\
\hline Control & 10 & 64.6 & 28.7 & \\
\hline Methanol seeds extract- Immediately & 10 & 94.9 & 4.8 & 0.009 \\
\hline Control & 10 & 64.6 & 28.7 & \\
\hline Methanol seeds extract- $1 \mathrm{~h}$ & 10 & 98.8 & 0.9 & 0.004 \\
\hline Control & 10 & 64.6 & 28.7 & \\
\hline
\end{tabular}

Significant difference between percentage of un sickle among leafs extract and control was observed with $P$ value $(<0.05)$. Table 3 . 
Table 3

Percentage of unsickle cells among leaves extract and control

\begin{tabular}{|c|c|c|c|c|}
\hline & $\mathbf{N}$ & Mean & Std. Deviation & P. value \\
\hline Aqueous leafs extract - Immediately & 10 & 93.3 & 5.7 & 0.012 \\
\hline Control & 10 & 64.6 & 28.7 & \\
\hline Aqueous leafs extract $-1 \mathrm{~h}$ & 10 & 97.9 & 1.8 & 0.005 \\
\hline Control & 10 & 64.6 & 28.7 & \\
\hline Methanol leafs extract- Immediately & 10 & 92.3 & 6.1 & 0.014 \\
\hline Control & 10 & 64.6 & 28.7 & \\
\hline Methanol leafs extract- $1 \mathrm{~h}$ & 10 & 98.4 & 1.1 & 0.005 \\
\hline Control & 10 & 64.6 & 28.7 & \\
\hline
\end{tabular}

Regarding difference between seeds and leaves extract, there was no significant difference on $\%$ of un sickle cells. P value (>0.05) Table 4 . Difference between both seeds extracts and both leaves extracts was evaluated; there was no significant difference between seeds aqueous and methanol extracts neither leaves aqueous nor methanol extracts but the significant difference occurred in the incubation time interval; significant difference was found when testing immediately and after $1 \mathrm{hr}$ incubation in all extracts. Tables $5 \& 6$.

Table 4

Percentage of unsickle cells among seeds and leaves extract

\begin{tabular}{|llllll|}
\hline & Extract & $\mathbf{N}$ & Mean & Std. Deviation & P.value \\
\hline aqueous- Immediately & Seeds & 10 & 94.7 & 4.7 & 0.537 \\
\cline { 2 - 5 } & Leafs & 10 & 93.3 & 5.7 & \\
\hline aqueous- 1 h & Seeds & 10 & 99.0 & 0.7 & 0.083 \\
\cline { 2 - 5 } & Leafs & 10 & 97.9 & 1.8 & \\
\hline Methanol - Immediately & Seeds & 10 & 94.9 & 4.8 & 0.301 \\
\cline { 2 - 5 } & Leafs & 10 & 92.3 & 6.1 & \multirow{2}{*}{0.405} \\
\hline Methanol- 1 h & Seeds & 10 & 98.8 & 0.9 & \\
\cline { 2 - 5 } & Leafs & 10 & 98.4 & 1.1 & \\
\cline { 2 - 5 } & & & &
\end{tabular}


Table 5

Percentage of unsickle cells among leaves extract

\begin{tabular}{|c|c|c|c|c|}
\hline Leafs extract(I) & Leafs extract(II) & Mean (I) & Mean (II) & P. value \\
\hline \multirow{3}{*}{$\begin{array}{l}\text { aqueous- } \\
\text { Immediately }\end{array}$} & aqueous- $1 \mathrm{~h}$ & \multirow[t]{3}{*}{$93.3 \pm 5.7$} & $97.9 \pm 1.8$ & .021 \\
\hline & Methanol- Immediately & & $92.3 \pm 6.1$ & .609 \\
\hline & Methanol - $1 \mathrm{~h}$ & & $98.4 \pm 1.1$ & .011 \\
\hline \multirow[t]{2}{*}{ aqueous- $1 \mathrm{~h}$} & Methanol- Immediately & $97.9 \pm 1.8$ & $92.3 \pm 6.1$ & .006 \\
\hline & Methanol - $1 \mathrm{~h}$ & & $98.4 \pm 1.1$ & .780 \\
\hline Methanol-Immediately & Methanol - $1 \mathrm{~h}$ & $92.3 \pm 6.1$ & $98.4 \pm 1.1$ & .003 \\
\hline
\end{tabular}

Table 6

Percentage of unsickle cells among seeds extract

\begin{tabular}{|c|c|c|c|c|}
\hline Seeds extract (I) & Seeds extract (II) & Mean (I) & Mean (II) & P. value \\
\hline \multirow[t]{3}{*}{ aqueous- Immediately } & aqueous- $1 \mathrm{~h}$ & \multirow[t]{3}{*}{$94.7 \pm 4.7$} & $99.0 \pm 0.7$ & 0.008 \\
\hline & Methanol- Immediately & & $94.9 \pm 4.8$ & 0.912 \\
\hline & Methanol- $1 \mathrm{~h}$ & & $98.4 \pm 0.9$ & 0.011 \\
\hline \multirow[t]{2}{*}{ aqueous- $1 \mathrm{~h}$} & Methanol- Immediately & \multirow[t]{2}{*}{$99.0 \pm 0.7$} & $94.9 \pm 4.8$ & 0.010 \\
\hline & Methanol- $1 \mathrm{~h}$ & & $98.4 \pm 0.9$ & 0.888 \\
\hline Methanol- Immediately & Methanol- $1 \mathrm{~h}$ & $94.9 \pm 4.8$ & $98.4 \pm 0.9$ & 0.014 \\
\hline
\end{tabular}

\section{Discussion}

Moringa oleifera has been reported to contain a rich store of elements like zinc, which possesses antisickling activity, as well as organic acids. Leaves are also rich sources of flavonols, which could be responsible for the exhibited antisickling activities [7]. This study evaluated the anti sickling activity of Moringa Oleifera leaves and seeds extracts. Antisickling activity of the seeds' butanol fraction was significantly $(P<0.05)$ higher at $20 \mathrm{mg} / \mathrm{ml}$ concentration and that of ethylacetate fraction, at $10 \mathrm{mg} / \mathrm{ml}$ concentration. The Ethyl acetate fraction of moringaoleifera leaf (at both tested concentrations), as well as the butanol fraction (at $20 \mathrm{mg} / \mathrm{ml}$ ), caused lysis of the blood [3]; that's why this study had chosen the aqueous and methanol extractions at this concentration.

This study observed that both the seed and leaves (aqueous and methanol) fractions of Moringa oleifera exhibited a significantly high antisickling activity, there is a slightly increase in the percentage of un sickle among seeds extracts than leaves extracts; this could be attributed to the fact that leaves had saponins, while the seeds had anthraquinones and alkaloids in addition to saponins. This results agree with former study by Adjemo, et al in Nigeria [7]. It has been reported that the mode of preparation of traditional 
recipes, as stipulated by the herb seller, was by decoction with clean water [8]. The experiential significantly higher $(P<0.05)$ antisickling activity of aqueous extract in this study, supports this, and it is believed that oxidative damage to cells is responsible for the activation of $\mathrm{KCl}$-co-transport in sickled erythrocytes [8]. For this reason the antisickling activity of the aqueous extracts were slightly higher than the methanol extracts.

This study also concluded that the one hour incubation period with extract have a significant effect on the percentage of un-sickled erythrocytes than the non incubated ones, However the result of this study is contrary to other authors [7] who reported that: results of antisickling bioassay for both aqueous and methanol extracts of moringaoleifera seed showed that there was no significant difference $(P>0.05)$ between the antisickling activity exhibited at the end of the 2 hrs incubation period.

Moringa oleifera previous studies revealed that it contains many phytochemicals such as Saponins were detected in all the three plant organs studied. Free anthraquinone was found only in the flower and alkaloids only, in the seed [7]. The antioxidative properties of Moringa oleifera had been reported in literature. It then becomes probable that the observed antisickling properties of Moringa oleifera seed, leaves and flower fractions could possibly be due to its innate antioxidants and phytochemicals [7].

None of the traditional recipes that are used in SCD management in Sudan contained Moringa oleifera as a constituent to the best of our knowledge. Therefore, this study meant to test the antisickling effects of a common edible plant in Sub-Saharan Africa where sickle cell disease is most prevalent presents a platform to explore the use of Moringa oleifera for the management of sickle cell disease patients.

\section{Conclusions}

Findings from the present study suggest the antisickling potentials of the seed and leaves of Moringa oleifera, so it could be a cost effective way for combating sickle cell disease complications. Widespread biological evaluations to generate in vivo accessibility data are needed and further studies will be necessary for the chemical characterization of the antisickling principles.

\section{Abbreviations}

(SCD): Sickle cell disease; (SCA): Sickle cell anemia; (HU): Hydroxyurea, (HBSS): Hemoglobin SS; (EDTA): Ethylenediaminetetraacetic acid; (Na205S2): Sodium metabisulfite; SPSS: Statistical package for the social sciences.

\section{Declarations}

\section{Ethics approval and consent to participate}

Available from Alzaeim Alazhari University and verbal consent to participants. 


\section{Consent to publish}

Not applicable

\section{Availability of data and materials}

All data generated or analysed during this study will be available to public without restrictions.

\section{Competing interests}

The authors declare that they have no competing interests.

\section{Funding}

Not applicable

\section{Authors' Contributions}

Rayan Hamid Omer: designed and performed the experiments related to aqueous extracts preparation, Nusiba Abdullah Yousif : designed and performed the experiments related to methanolic extracts preparation Toga Abdalazim Fadlalla: analyzed and interpreted the data, Wala Eldin Osman Elradi: drafted the manuscript, Mohammed Mobarak Elbasheir: revised the manuscript critically and Elharam Ibrahim Abd allah: conceived and supervised this study. All authors read and approved the final version of manuscript.

\section{Acknowledgments}

Special thanks to the staff of Khartoum teaching hospital and all candidates who participated in this study.

\section{References}

1. Ware RE. Is sickle cell anemia a neglected tropical disease? : Public Library of Science; 2013.

2. Piel FB, Hay SI, Gupta S, Weatherall DJ, Williams TN. Global burden of sickle cell anaemia in children under five, 2010-2050: modelling based on demographics, excess mortality, and interventions. PLoS medicine. 2013; 10 (7):e1001484.

3. Mpiana P, Mudogo V, Ngbolua K, Tshibangu D, Shetonde O, Mbala M. In vitro antisickling activity of anthocyanins from Ocimum basilicum L.(Lamiaceae). International Journal of Pharmacology. 
2007;3(4):371-4.

4. Nwaoguikpe R, Ujowundu C, Igwe C, Dike C. The effects of Moringa oleifera leaves extracts on Sickle Cell Hemoglobin. J Scientific Res \& Reports. 2015;4(2):123-32.

5. Rockwood J, Anderson B, Casamatta D. Potential uses of Moringa oleifera and an examination of antibiotic efficacy conferred by M. oleifera seed and leaf extracts using crude extraction techniques available to underserved indigenous populations. International Journal of Phytotherapy Research. 2013;3(2):61-71.

6. Kasolo JN, Bimenya GS, Ojok L, Ochieng J, Ogwal-Okeng JW. Phytochemicals and uses of Moringa oleifera leaves in Ugandan rural communities. Journal of Medicinal Plants Research. 2010;4(9).

7. Adejumo OE, Kolapo AL, Folarin AO. Moringa oleifera Lam.(Moringaceae) grown in Nigeria: In vitro antisickling activity on deoxygenated erythrocyte cells. Journal of pharmacy \& bioallied sciences. 2012;4(2):118.

8. Adam MA, Adam NK, Mohamed BA. Prevalence of sickle cell disease and sickle cell trait among children admitted to Al Fashir Teaching Hospital North Darfur State, Sudan. BMC Research Notes. 2019;12(1):1-6.

\section{Figures}
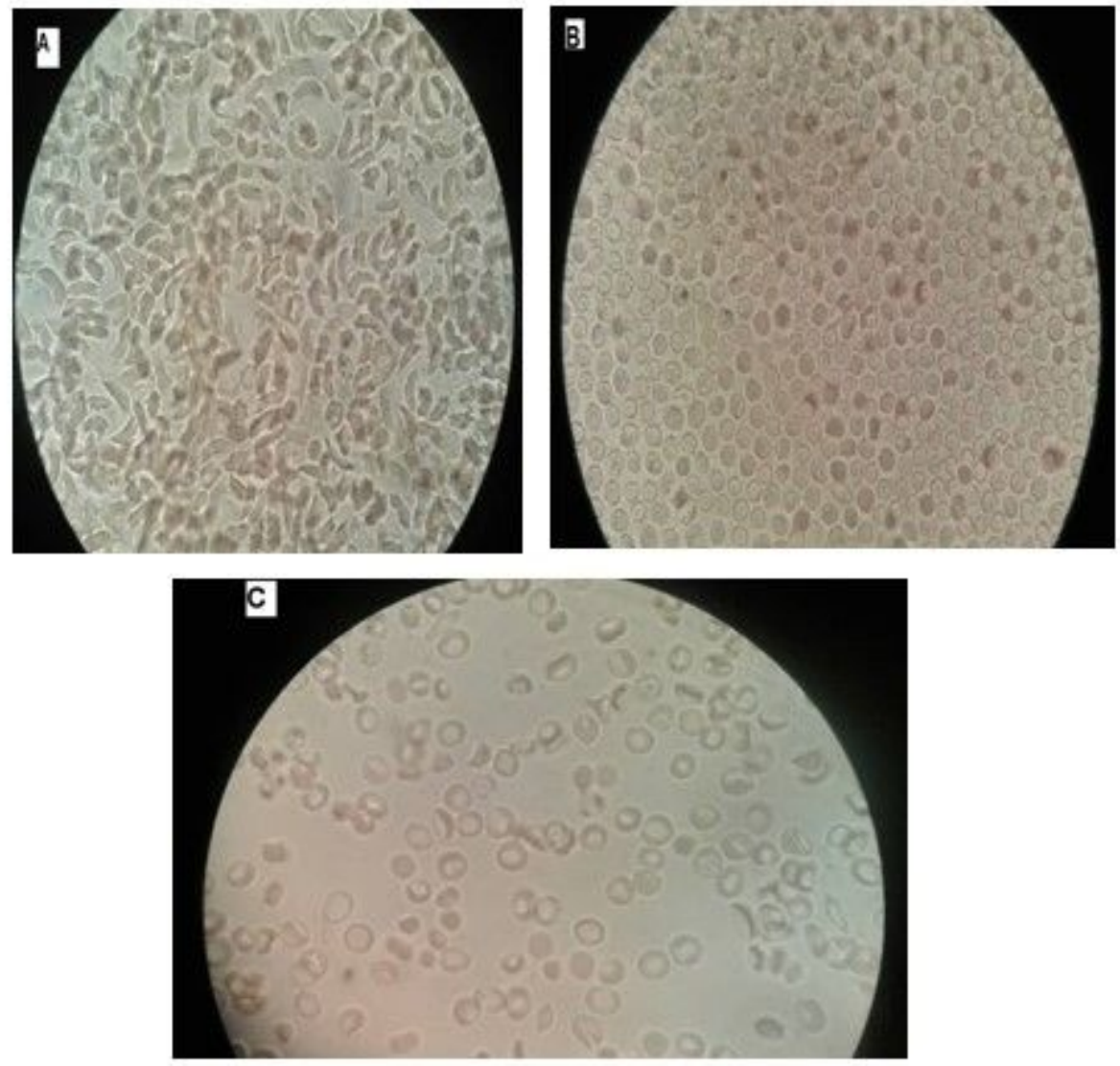

Figure 1 
sickling test; (Microscope photograph was taken for the slide with Moringa extract and control); [A] No of un-sickle cells versus sickle cells after addition of control (normal saline), [B] No of un-sickle cells versus sickle cells after adding of Moringa oleifera aqueous extract, [C] No of un-sickle cells versus sickle cells after adding of Moringa oleifera methanol extract. 